disorder, suicidality, anxiety, alcohol or drug misuse and post-traumatic stress disorder.

columns
- Because of the association between domestic violence and poor mental health, enquiry about domestic violence in the past and present should be included as part of the clinical assessment of all patients (men and women) and families.

- Victims are unlikely to disclose domestic violence spontaneously to health professions and should be specifically asked.
- Routine questioning of patients about domestic violence experiences has been found to be acceptable to, and indeed welcomed by, patients.

- Attempting to leave increases the danger for the woman and is likely to precipitate an escalation in the violence against her.

- Psychiatrists need to be aware of the severe and enduring effects of domestic violence on children and its association with child abuse.

- All reported cases of domestic violence require a risk assessment.
- Key interventions include: establishing the victim's safety, treating mental illness, providing information about local resources and assessing current and future risk.

- Psychiatrists should also be familiar with treatment and approaches, resources and risk assessment for perpetrators.

- Specific training on domestic violence at pre- and post-membership should be introduced into the curriculum and continued through professional development

\title{
obituaries
}

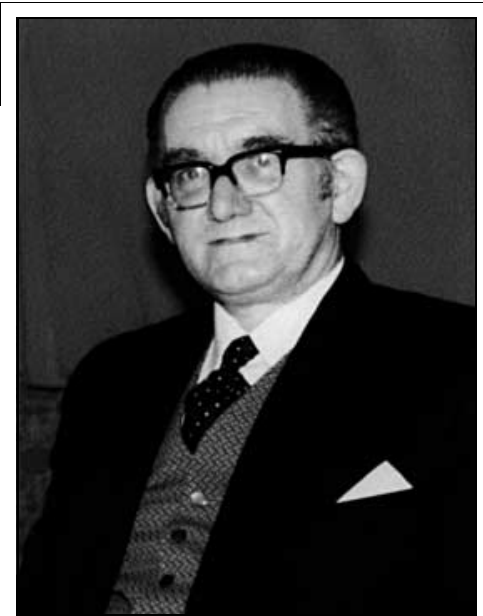

Brian Ward

Formerly Medical

Superintendent, Winwick Hospital

Born in Dewsbury, Yorkshire, Brian qualified MB ChB (Manchester) with three distinctions in his finals. He worked for several Manchester hospitals in his early years and was then appointed area psychiatrist for the Northern Command of the armed forces. His career developed further when he became the senior registrar at the Department of Psychiatry in Leeds and then again with his appointment as the medical officer for the Leeds Regional Hospital Board (1960-1964), with responsibility for provision of psychiatric and elderly care for the Yorkshire area. He was also involved in the planning of Airedale General Hospital. At 35, he was the youngest ever NHS appointee to the position of medical superintendent of Winwick Hospital in Cheshire. He was elected FRCPsych in 1972.

For 25 years, between 1963 and 1987, Dr Brian Ward was the Medical Superintendent of Winwick Hospital, then the Chairman of Psychiatry in Warrington, leading the largest mental institution in
Europe in the 1960s, 70s and 80s. Brian masterminded, with a great and rare combination of compassion, wisdom, vision and leadership, the process of 'running down' Winwick asylum, which accommodated over 2000 psychiatric inpatients. By the time of his retirement, the size of Winwick asylum in Warrington was reduced by over $50 \%$. This was done with the least possible distress to patients and carers, to whom he was so devoted. The closure of Winwick Hospital was finalised, but not without difficulties 10 years after he retired.

Brian was very active in both the Royal Medico-Psychological Association (RMPA) and the early days of the Royal College of Psychiatrists. He was secretary of the North West Division of the RMPA and later the same division of the College until 1975. He was secretary of the College Public Policy Committee from 1983 to 1986 . His medical administrative expertise was shown at a College meeting in 1974, when he presented, together with Julian Leff, a report on 'Confidentiality and Medical Records'. His views continued to be sound, relevant and true.

At home, Brian was a great 'do-it-yourself' man and one of his favourite pastimes was maintaining and overhauling the 'vintage' fleet of Triumph Standard cars that he loved. He was immensely practical and inventive, but his main joy was music. He was an accomplished musician and began playing saxophone and clarinet at the age of 13. He led and played with a band at prestigious events country wide. His favourite music was jazz: his band had a huge repertoire, ranging from the Glenn Miller variety through to present day hits. Even when his illness prevented him from attending recent bookings, he continued to write and put together the musical programme for each event.

Brian died peacefully on 12 October 2002 aged 75, after a long illness that he endured with courage and dignity. He leaves his wife, Joan, daughter Barbara and son Richard.

Emad Salib and Janet Connah

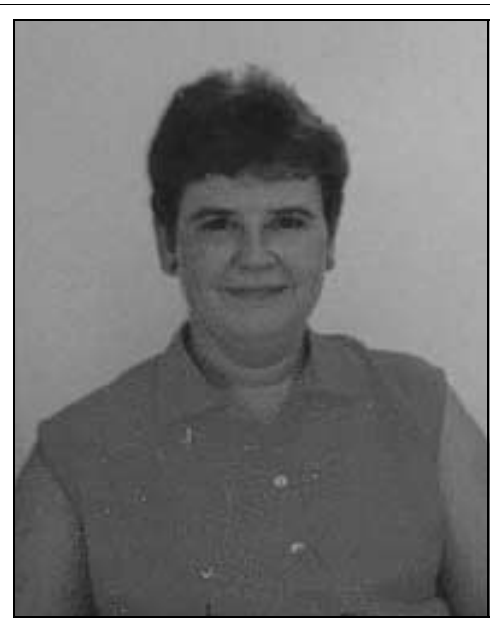

\section{Dr Gabrielle Maria Kearney}

\section{Formerly Consultant}

Psychiatrist, The Hesketh

Centre, Southport, Merseyside

Gabrielle Kearney, Consultant Adult General Psychiatrist, died at a local Hospice aged 42. She was a compassionate woman who will be greatly missed by family, friends and colleagues.

Born in Liverpool in 1960, Gabby, as she was always known, attended Notre Dame High School in Woolton. She studied Medical Microbiology at the University of Dundee, gaining a BSc (Hons) in 1984. She remained in Dundee to study medicine, qualifying in 1987. After completing her pre-registration year, she was appointed to the North Staffordshire/South Cheshire Psychiatric Training Scheme based at the Department of Postgraduate Medicine, University of Keele. She was elected MRCPsych in 1991 and joined the North Wales Higher Psychiatric Training Scheme in August 1992.

Gabby took up post as a full-time Consultant Psychiatrist in Southport in January 1996, and continued working at the Hesketh Centre until shortly before her death. She was involved in providing 